\title{
Economics of processing and marketing of different value added products of grapes in north Karnataka
}

\section{K.S. THIPPANNA, M.K. SHWETHA, BALACHANDRA K. NAIK AND N. SRINIVAS}

\begin{abstract}
The present study on economics of processing and marketing of grapes in raisin and wine making was conducted in Vijayapura and Belagavi districts of north Karnataka. Based on the higher concentration of area and production of the fruits, the objective to analyze the costs and returns in processing grapes into different value added products like raisins and wine was conducted. The results were based on primary data collected, with the sample size of eight processing units, twenty wholesaler cum commission agents and twenty retailers for each of the value added product. The results revealed that the total cost incurred by the processors in processing of grapes into one quintal of raisin and hundred lit of wine was of Rs. 5835and Rs. 5856, respectively. The degree of value addition in the cases of grape raisin and grape wine was found to be 56.22 and 56.88 per cents, respectively. The marketing cost incurred by the retailers in marketing one quintal of grape raisin and hundred lit of grape wine was found to be Rs. 95 and Rs. 65, respectively. Since the stake holders in value chain of both the cases of value added products (raisin and wine) are not integrated, there is a great opportunity to integrate and strengthen the value chain in processing and marketing of those value added final products. The concerned statutory bodies have to give due attention for providing proper approach roads to the farms, processing units, cold storage and marketing facilities.
\end{abstract}

KEY WORDS : Value chain, Processing, Marketing, Raisin, Grape wine

How to cite this paper : Thippanna, K.S., Shwetha, M.K., Naik, Balachandra K. and Srinivas, N. (2016). Economics of processing and marketing of different value added products of grapes in north Karnataka. Internat. J. Com. \& Bus. Manage, 9(2) : 169-174. DOI: 10.15740/HAS/IJCBM/9.2/169-174.

\section{MEMBERS OF THE RESEARCH FORUM}

Correspondence to:

M. K. SHWETHA, Department of Agribusiness Management, College of Agriculture, University of Agricultural Sciences, DHARWAD (KARNATAKA) INDIA

Email: shwethamrutha@gmail.com

\section{Authors' affiliations:}

K.S. THIPPANNA, BALACHANDRA K. NAIK AND N. SRINIVAS,

Department of Agribusiness Management, College of Agriculture, University of Agricultural Sciences, DHARWAD (KARNATAKA) INDIA 